DAFTAR ISI

Pengantar Redaksi

Daftar Isi

iv

Pemikiran Al-Sa'dî tentang Kriteria Pegawai Profesional (Studi Terhadap Q.S. Al-Qashash [28]: 26, Hadits-hadits Terkait, dan Kajian Lainnya)

Prinsip-Prinsip Muamalah dalam Islam

Analisis Kesehatan Finansial dan Kinerja Sosial (Studi Kasus Bank Muamalat Indonesia dan Bank Syariah Mandiri)

Moratorium (Inzhar ad-Dain) dalam Tinjauan Hukum Islam

Jual Beli dalam Perspektif Al-Qur'an

93 


\title{
PEMIKIRAN AL-SA'DÎ TENTANG KRITERIA PEGAWAI PROFESIONAL (Studi Terhadap Q.S. Al-Qashash [28]: 26, Hadits-hadits Terkait, dan Kajian Lainnya)
}

\author{
Rahendra Maya \\ Dosen Tetap Prodi Pendidikan Agama Islam \\ Sekolah Tinggi Agama Islam (STAI) Al Hidayah Bogor \\ rahendra.maya76@gmail.com dan rmaboeaisy@gmail.com
}

\begin{abstract}
Abstrak
Bekerja untuk memenuhi kebutuhan hidup dan dalam rangka memperoleh penghasilan untuk menjaga eksistensi kehidupan merupakan kewajiban dan tanggung jawab setiap orang. Dalam Islam, bekerja dan/atau menjadi pegawai dalam suatu bidang profesi tertentu bahkan dikategorikan sebagai kewajiban agama yang bernilai ibadah. Di samping itu, Islam pun memberikan tuntunan agar pekerjaan dilaksanakan sesuai dengan kompetensi atau profesionalitas, spesifiknya berdasarkan kekuatan dan keamanahan seperti yang sangat jelas diungkapkan Allah S.W.T. dalam Q.S. Al-Qashash [28]: 26 dan oleh Rasulullah S.A.W. dalam haditsnya. Karena itu, memahami kriteria kekuatan (quwwah) dan keamanahan (amânah) pegawai plus kejujurannya (shidq) serta substansi dari karakter kepegawaian tersebut merupakan hal yang sangat urgen untuk dilakukan, antara lain melalui pemikiran seorang ulama dalam menafsirkan ayat, hadits, dan kajian lainnya yang terkait. Makalah ini diupayakan untuk mengungkap tema urgen tersebut melalui pemikiran AlSa'dî yang diklasifikasi sebagai salah seorang ulama kontemporer yang kompeten di banyak bidang keilmuan melalui karya-karyanya yang bernas dan ilmiah.
\end{abstract}

Kata kunci: profesional, kriteria pegawai, pegawai profesional, kuat, amanah. 


\begin{abstract}
Working to meet the necessities of life and in order to earn an income to maintain the existence of life is the duty and responsibility of everyone. In Islam, working and/or being an employee in a particular field of profession is even categorized as a religious obligation worthy of worship. In addition, Islam also provides guidance for the work carried out in accordance with the competence or professionalism, specifically based on strength and security as is very clearly expressed Allah S.W.T. in Q.S. Al-Qashash [28]: 26 and the prophet Muhammad in his (hadith). Therefore, understanding the criteria of strength (quwwah) and the security (amânah) of employees plus its honesty (shidq) and the substance of the staffing character is very urgent to do, among others through the thought of a scholar in interpreting verses, hadith, and other studies related. This paper seeks to uncover the urgent theme through the thought of Al-Sa'dî which is classified as one of the contemporary scholars competent in many fields of science through his pithy and scientific works.
\end{abstract}

Keyword: professional, employee criteria, professional employer, strong, trustworthy.

\section{A. PENDAHULUAN}

Ajaran Islam dalam berbagai aspeknya bila dipahami lebih lanjut dan dikaji secara mendalam -demikian seharusnya-, maka tidak hanya memandu dan membimbing kaum Muslimin secara spesifik dan umat manusia secara general tentang masalah keagamaan semata, namun juga banyak menyorot tentang aspek keduniawian yang erat kaitannya dengan kehidupan keseharian umat manusia, antara lain tentang profesi atau pekerjaan dan tentang kriteria pegawai yang handal atau profesional.

Islam datang dengan memberikan motivasi atraktif kepada umat manusia untuk bekerja dan mencari penghasilan untuk memenuhi kebutuhan dan bagi kelangsungan hidup. Tidak hanya itu, Islam secara tegas bahkan mengklasifikasi kemauan dan kemampuan life skills (dalam bekerja) sebagai hal mulia yang bernilai ibadah dan termasuk dalam kewajiban beragama, ${ }^{1}$ yang harus diberikan atensi perhatian dan bahkan sebagai hal yang sangat ditekankan.

Al-Qur'an sebagai sumber asasi dan landasan fundamental dalam Islam, selain banyak mengungkap term kerja ('amal, fi'l)

\footnotetext{
1 Lihat Rahendra Maya. (2015). "Perspektif Islam Tentang Konsep Life Skills Education". Edukasi Islami: Jurnal Pendidikan Islam. Program Studi Pendidikan Agama Islam Jurusan Tarbiyah Sekolah Tinggi Agama Islam (STAI) Al Hidayah Bogor. Vol. 04 No. 07 Edisi Januari 2015. h. 872873.
} 
dan term lain yang semisal dengan pelbagai bentuk derivasinya (isytiqâq), juga mendeskripsikan tentang kriteria pengangkatan pegawai dan salah satu model pengupahannya.

Hal ini antara lain terdapat dalam tiga term yang diungkap dalam Q.S. AlQashash [28]: 26-28 ${ }^{2}$ dengan menggunakan

${ }^{2}$ Lengkapnya Allah S.W.T. berfirman sebagai berikut:

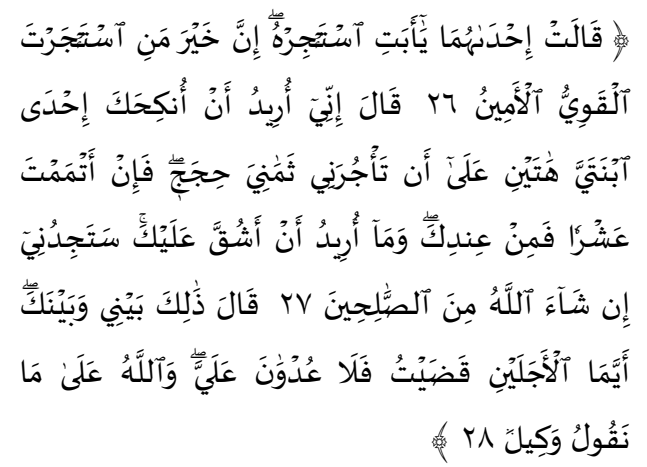

Salah seorang dari kedua perempuan itu berkata, "Wahai ayahku! Jadikanlah dia sebagai pekerja (pada kita), sesungguhnya orang yang paling baik yang engkau ambil sebagai pekerja (pada kita) adalah orang yang kuat dan dapat dipercaya.”. Dia (Syu'aib) berkata, "Sesungguhnya aku bermaksud ingin menikahkan engkau dengan salah seorang dari kedua anak perempuanku ini, dengan ketentuan bahwa engkau bekerja padaku selama delapan tahun, dan jika engkau sempurnakan sepuluh tahun, maka itu adalah (suatu kebaikan) darimu, aku tidak bermaksud memberatkan engkau. Dan Insya Allah engkau akan mendapatiku termasuk orangorang yang baik.”. Dia (Musa) berkata, "Itulah (perjanjian) antara aku dan engkau. Yang mana saja dari kedua waktu yang ditentukan itu yang aku sempurnakan, maka tidak ada tuntutan (tambahan) atas diriku (lagi). Dan Allah adalah saksi atas apa yang kita ucapkan.”.

Lihat Umay M. Dja'far Shiddieq. (2016). Mushaf Tafhim Al-Qur'an Daarul 'Amal. term ta juranî (engkau bekerja kepadaku), ista jarta (engkau mempekerjakan), dan ista jirhu (jadikanlah ia pegawaimu), ${ }^{3}$ yang dengan jelas menunjukkan adanya pihak yang mempekerjakan (atasan atau mitra kerja), orang yang bekerja (pegawai atau mitra kerja), jenis pekerjaan, dan upah yang diberikan sebagai imbalan dari hasil kerjanya.

Ketika ditelusuri dalam kitab-kitab tafsir dan sebagaimana yang terekam dengan sangat jelas dalam ayat, kisah tersebut berkaitan dengan kisah Nabi Musa dengan dua anak gadis dan orang tuanya, yaitu bapaknya yang kemudian mengangkat Musa sebagai pegawainya dengan upah yang dipersyaratkan dan telah disepakati sebelumnya. Bentuk profesi yang terjadi saat itu memang dalam bentuk yang masih sederhana, yaitu menggembala dan memberi minum kambing yang menjadi ternak peliharaan mereka.

Dalam Al-Hadits, banyak sekali teksteks hadits sebagai sabda Rasulullah S.A.W. yang mengungkap tentang hakekat profesi dan menyingkap tentang kriteria pegawai yang profesional serta hal-hal lain

Sukabumi: Yayasan Pendidikan dan Sosial Islam Daarul 'Amal. h. 388.

${ }^{3}$ Muhammad Fu'âd 'Abd Al-Bâqî. (1988). AlMu'jam Al-Mufahras li Alfâzh Al-Qur'ân Al-Karîm. Beirut: Dâr Al-Jîl. h. 12; dan Husain Muhammad Fahmî Al-Syâfî̀i. (2008). Al-Dalîl Al-Mufahras li Alfâzh Al-Qur'ân Al-Karîm. Kairo: Dâr al-Salâm. h. 69. 
yang berhubungan dengan profesi dan status kepegawaian tersebut.

Demikian pula dengan penjelasan para ulama Islam, terutama ketika menafsirkan atau menginterpetasikan ayat-ayat AlQur'an dan menjelaskan (syarh) teks-teks Al-Hadits tentang kriteria pegawai yang profesional tersebut.

Ini memberikan indikasi kuat bahwa bekerja secara umum dan dengan menjadi pegawai bagi orang atau pihak lain secara spesifik, dalam Islam tidak hanya berstatus hukum diperbolehkan atau disyariatkan, namun juga harus didasarkan pada kompetensi pekerjaan atau profesionalitas kepegawaian yang handal. Yaitu didasarkan kepada kriteria kekuatan (quwwah) dan keamanahan (amânah) serta kejujuran (shidq), sehingga pegawai tersebut merupakan orang yang kuat (qawî) lagi terpercaya (amîn) dan jujur (shiddîq) serta memiliki standar kriteria lain yang terkait erat dengan karakter-karakter tersebut.

Hal ini secara filosofis-ideologis seharusnya dapat membimbing dan mampu memotivasi setiap Muslim untuk menjadi pegawai handal yang profesional yang bukan hanya untuk mengentaskan kemiskinan dan meningkatkan taraf hidup, namun menghasilkan karya nyata atau yang hasil kerja optimal.
Al-Sa'dî termasuk di antara ulama kontemporer yang mengapresiasi dan mendeskripsikan kedua kriteria utama bagi pegawai profesional tersebut dan karakter lain yang terkait dalam berbagai karyanya yang terkait pembahasan, antara lain kitab Taisîr Al-Karîm Al-Rahmmân fî̀ Tafsîr Kalâm Al-Mannân, Taisîr Al-Lathîf Al-Mannân fî̀ Khulâshah Tafsîr Al-Qur'ân, Bahjah Qulûb Al-Abrâr wa Qurrah 'Uyûn Al-Akhyâr fî̀ Syarh Jawâmi' Al-Akhbâr, dan Al-Riyâdh

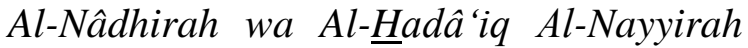
Al-Zâhirah fî̀ Al-'Aqâ'id wa Al-Funûn AlMutanawwi'ah Al-Fâkhirah serta karyakarya lainnya.

\section{B. RUMUSAN MASALAH}

Untuk mengetahui corak pemikiran AlSa'dî tentang kriteria pegawai profesional, maka terlebih dahulu harus ditelusuri pemikirannya tersebut berdasarkan studinya terhadap ayat dan hadits serta kajian lainnya yang sesuai dengan tema pembahasan.

Oleh karena itu, dalam makalah ini rumusan masalahnya adalah ditujukan untuk mengungkap pemikiran Al-Sa'dî dalam interpretasinya (tafsîr) terhadap Q.S. Al-Qashash [28]: 26, anotasi penjelasannya (syarh) terhadap haditshadits yang berkaitan, dan kajian lainnya yang terkait dengan kriteria pegawai profesional yang secara spesifik memiliki 
kekuatan (quwwah) dan keamanahan (amânah) plus karakter kejujuran (shidq) yang terkait erat dengan keamanahan.

\section{HASIL PEMBAHASAN DAN DISKUSI}

\section{Pegawai Profesional}

Dalam Kamus Besar Bahasa Indonesia, yang dimaksud dengan pegawai adalah (a) orang yang bekerja pada pemerintah (perusahaan dan sebagainya); (b) orang yang bekerja pada kerajaan; (c) alat perkakas; dan (d) sekelompok orang yang bekerja sama membantu seorang direktur, ketua, dan sebagainya mengelola sesuatu. ${ }^{4}$

Adapun dalam Bahasa Arab, pegawai diistilahkan dengan term ajîr, secara sederhana didefinisikan sebagai orang yang bekerja untuk mendapatkan upah (man ya'malu bi ajr), ${ }^{5}$ dan atau balasan lain yang semisal dan sepadan dengannya, tentunya sesuai dengan ketentuan yang berlaku.

Dari definisi tersebut dapat dipahami bahwa pegawai sinonim dengan pekerja atau istilah lainnya yang ekuivalen, intinya adalah orang atau sekelompok orang yang

4 Departemen Pendidikan Nasional. (2012). Kamus Besar Bahasa Indonesia Pusat Bahasa: Edisi Keempat. Jakarta: PT Gramedia Pustaka Utama. h. 1037.

5 Majma' Al-Lughah Al-'Arabiyyah Jumhûriyyah Mishr Al-'Arabiyyah. (2012). AlMu'jam Al-Wajîz. Mesir: Maktabah Al-Syurûq AlDauliyyah. h. 7. bekerja kepada orang lain ataupun pihak lainnya sesuai dengan bidang kerja yang digelutinya untuk kemudian mendapatkan sejumlah upah dari hasil kerjanya tersebut.

Sedangkan maksud dari profesional yang menjadi sifat bagi pegawai -yaitu pegawai profesional- adalah bersangkutan dengan profesi; (b) memerlukan kepandaian khusus untuk menjalankannya; dan (c) mengharuskan pembayaran untuk melakukannya (lawan amatir). ${ }^{6}$

Term profesional sendiri berasal dari akar kata profesi yang menunjukkan suatu pekerjaan tertentu yang menuntut persyaratan khusus dan istimewa sehingga memperoleh kepercayaan dari pihak yang membutuhkan. ${ }^{7}$

Berdasarkan definisi tersebut di atas dapat disimpulkan bahwa profesional -atau profesionalitas- berkaitan dengan suatu bidang profesi atau pekerjaan tertentu yang memerlukan keahlian khusus atau kompetensi tertentu berdasarkan profesionalitasnya sehingga layak untuk mendapatkan gaji atau upah dari profesi dan pekerjaannya tersebut.

\footnotetext{
${ }^{6}$ Departemen Pendidikan Nasional. (2012). h. 1104.

${ }^{7}$ Ramayulis. (2013). Profesi \& Etika Keguruan. Jakarta: Kalam Mulia. h. 27-28.
} 
2. Kekuatan (Quwwah), Keamanahan (Amânah), dan Kejujuran (Shidq) dalam Bekerja

Yang dimaksud dengan kuat adalah (a) banyak tenaganya (gayanya, dayanya), mampu mengangkat (mengangkut dan sebagiannya) banyak; (b) tahan (tidak mudah patah, rusak, putus, dan sebagainya); (c) tidak mudah goyah (terpengaruh), teguh (tentang iman, pendirian, kemauan, dan sebagainya); (d) ketat (tentang pertahanan, penjagaan, dan sebagainya); (e) tahan (menderita sakit dan sebagainya); (f) kencang (tentang angin); (g) berat (tekanannya); (h) keras, nyaring; (i) erat (tentang ikatan); (j) mampu dan kuasa (berbuat sesuatu); dan (k) mempunyai kesungguhan (kecakapan dan sebagainya) dalam suatu pengetahuan (kecakapan). Kekuatan biasanya secara mudah sering dipahami sebagai (a) perihal kuat tentang tenaga, gaya; dan (b)

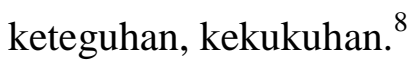

Kuat dalam Bahasa Arab diistilahkan dengan term quwwah, umumnya didefinisikan sebagai lawan dari lemah (dhidd al-dha'ff), ${ }^{9}$ atau kebalikan/versus dari kelemahan (naqîdh al-dha'f) yang umumnya berkaitan dengan kekuatan fisik

8 Lihat Departemen Pendidikan Nasional. (2012). h. 746-747.

9 Muhammad ibn Ya'qûb Al-Fairûzâbâdî. (2009). Al-Qâmûs Al-Muhîth. Beirut: Dâr Al-Kutub Al-'Ilmiyyah. h. 1333. dan rasionalitas, ${ }^{10}$ yaitu sifat yang membuat seseorang mampu mengerjakan sesuatu tanpa diiringi oleh kelemahan (shifah yatamakkanu al-fầil bihâ min al-fíl bi dûni dha'f). ${ }^{11}$

Dalam konteks makalah ini, kuat yang dimaksud adalah kekuatan fisik atau tenaga, kuat iman dan kemauan, serta kekuatan lainnya yang dapat menunjang kemampuan, kompetensi, kehandalan, dan keunggulan seseorang, termasuk dalam bekerja atau profesi pekerjaannya.

Sedangkan amanah berarti (a) sesuatu yang dipercayakan (dititipkan) kepada orang lain; (b) keamanan, ketenteraman; dan (c) dapat dipercaya (boleh dipercaya), setia. $^{12}$

Dalam Bahasa Arab amânah diidentifikasi sebagai sifat atau karakter yang terkait dengan berbagai hal yang dipikul dan menjadi tanggung jawab seseorang untuk ditunaikan, baik berkaitan dengan agama maupun urusan duniawi, berhubungan dengan ucapan maupun perbuatan. $^{13}$

${ }^{10}$ Lihat Muhammad ibn Mukrim ibn Manzhûr Al-Afrîqî Al-Mishrî. (2011). Lisân Al-'Arab. Beirut: Dâr Shâdir. Vol. 12. h. 229.

${ }^{11}$ Muhammad ibn Shâlih Al-'Utsaimîn. (1415 H.). Syarh Al-'Aqîdah Al-Wâsithiyyah li Syaikh AlIslâm Ibn Taimiyyah. Damam: Dâr Ibn Al-Jauzî. Vol. 1. h. 204.

${ }^{12}$ Departemen Pendidikan Nasional. (2012). h. 47.

13 Lihat Mâzin ibn 'Abd Al-Karîm Al-Furaih. (2004). Al-Râ'id: Durûs fî Al-Tarbiyah wa Al- 
Karena itu, dapat dinyatakan pula bahwa amanat dalam lingkup general adalah seluruh hal yang diwajibkan Allah S.W.T. kepada hamba-hamba-Nya (jamî' mâ iftaradha Allah ta'âlâ 'alâ al-'ibâd), ${ }^{14}$ seperti shalat, zakat, puasa, dan pelunasan hutang. Atau seluruh tanggung jawab yang diberikan Allah S.W.T. kepada umat manusia berupa profesi pekerjaan di bidang tertentu maupun berupa hak-hak yang harus ditunaikan (ma istar'â Allah ta'âlâ min

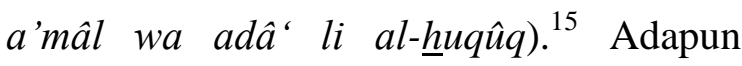
amanah yang paling ditekankan adalah amanah dalam hal titipan, sedang titipan yang paling ditekankan adalah menyembunyikan rahasia. Amanah juga berupa segala sesuatu yang dipercayakan untuk dijaga, baik itu harta, kehormatan, maupun rahasia. ${ }^{1617}$

Da'wah. Jeddah: Dâr Al-Andalus Al-Khadhrâ'. Vol. 1. h. 115

14 Ahmad Mu'âdz $\underline{\text { Haqqî. }}$ (1414 H.). AlArba'ûna Hadîtsan fî̀ Al-Akhlâq ma'a Syarhihâ. Riyadh: Dâr Thuwaiq. h. 57.

${ }^{15}$ Lihat Khâlid ibn ㅂâmid Al-Hâzimî. (2000). Ushûl Al-Tarbiyah Al-Islâmiyyah. Riyadh: Dâr 'Âlam Al-Kutub. h. 187.

16 Lihat Mahmud Al-Mishri. (2011). Ensiklopedia Akhlak Muhammad S.A.W. Jakarta: Pena Pundi Aksara. h. 532.

17 Menurut 'Abd Al-Rahmân Habanakah AlMaidânî, objektifitas dan ruang lingkup amanah (majâlât al-amânah) sangat banyak, selain amanat agama di antaranya amanat harta benda (amwal), kehormatan harga diri ( $a$ 'râdh), fisik-jasmani dan psikis-ruhani (ajsâm wa arwâh $)$, wawasan pengetahuan dan ilmu (ma'ârif wa 'ulûm), kepemimpinan (wilâyah), kesaksian (syahâdah),
Semua amanat tersebut harus dipenuhi karena dikategorikan sebagai janji yang harus dipenuhi dengan sebaik mungkin dan tanggung jawab yang harus ditunaikan dengan sebaik-baiknya.

Amanah dalam konteks makalah ini yang dimaksud adalah kepercayaan yang diberikan kepada dan dimiliki seseorang yang menjadikannya layak untuk mendapatkan tanggung jawab atau pekerjaan yang harus dipikul dan ditunaikannya dengan seoptimal mungkin.

Berkaitan dengan pekerjaan atau status dan tanggung jawab kepegawaian seseorang, dengan kekuatannya ia sanggup melaksanakan pekerjaan yang diembankan kepadanya, dan dengan amanah ia menunaikan sesuai dengan tugas dan tanggung jawabnya. Dengan amanah ia akan meletakkan perkara-perkara pada tempatnya, sedangkan dengan kekuatan ia sanggup menunaikan kewajibannya. ${ }^{18}$

keputusan (qadhâ), catatan administratif (kitâbah), rahasia (asrâr), dan pesan korespondensi (risâlât) serta pendengaran, penglihatan, dan indra lainnya (sam' wa bashar wa sâ 'ir al-hawâs).

Lihat 'Abd Al-Rahnmân Habanakah Al-Maidânî. (1999). Al-Akhlâq Al-Islâmiyyah wa Ususuhâ. Jeddah: Dâr Al-Basyîr dan Dâr Al-Qalam Damaskus. Vol. 1. h. 649-650.

18 Lihat Fachri Fachrudin. (2013). "Fikih Bekerja”. Al-Mashlahah: Jurnal Hukum Islam dan Pranata Sosial Islam. Program Studi Ahwal Syakhshiyah Jurusan Hukum Islam Sekolah Tinggi Agama Islam Al Hidayah Bogor. Vol. 01 No. 01 Edisi Januari 2013. h. 63. 
Jujur (shidq) adalah lawan dari dusta (kadzib), keduanya semula dinyatakan sebagai terma yang terkait dengan perkataan, baik tentang masa lalu atau hal mendatang, berkaitan dengan sebuah janji maupun selainnya. Yaitu keselarasan antara perkataan hati dengan realitas yang terwujud secara sinergis (muthâbaqah al-qaul al-dhamîr wa al-mukhbar 'anhu ma'an). ${ }^{1920}$

Dalam Bahasa Indonesia, jujur dimaknai dengan (a) lurus hati, tidak berbohong (misal dengan berkata apa adanya); (b) tidak curang (misal dalam permainan, dengan mengikuti aturan yang berlaku); dan (c) tulus, ikhlas. ${ }^{21}$

Sedangkan dalam konteks makalah, jujur (shidq) yang dimaksud adalah integritas kelurusan hati dengan selalu

19 Lihat Al-Râghib Al-Ashfahânî. (2001). AlMufradât fî Gharîb Al-Qur'ân. ed. Muhammad Khalîl 'Aitânî. Beirut: Dâr Al-Ma'rifah. h. 280.

${ }^{20}$ Menurut Ibn Al-Qayyim Al-Jauziyyah, jujur (shidq) merupakan level mulia yang sangat tinggi yang dapat digapai umat manusia, hanya berada di bawah level kenabian (darajah tâliyah li darajah alnubuwwah allatî hiya arfa'u darajât al-'âlamîn), sebagaimana firman Allah S.W.T. dalam Q.S. AlNisâ‘ [4]: 69.

Lihat Muhammad ibn Abî Bakr ibn Qayyim AlJauziyyah. (2003). Madârij Al-Sâlikîn baina Manâzil Iyyâka Na'budu wa Iyyâka Nasta'în. ed. 'Imâd 'Âmir. Kairo: Dâr Al-Hadîts. Vol. 2. h. 220; dan Shâlih ibn 'Abd Allah ibn Humaid. et.al. (2004). Mausû'ah Nadhrah Al-Na'îm fî Makârim Akhlâq Al-Rasûl Al-Karîm. Jeddah: Dâr Al-Wasîlah. Vol. 6. h. 2474.

${ }^{21}$ Departemen Pendidikan Nasional. (2012). h. 591. berusaha optimal untuk berkata dan berlaku jujur dalam bidang pekerjaan yang menjadi profesinya.

Walaupun secara simplistik sering dinyatakan sebagai sinonim, keamanahan (amânah) bila diungkapkan secara bersamaan dengan kejujuran ( $s h i d q)$, maka haruslah dibedakan karena memiliki perbedaan makna substansial walaupun sedikit, termasuk dalam profesi dan status kepegawaian. Jujur (shidq) adalah sifat atau karakter yang menjadi integritas kepribadian seseorang dalam pekerjaannya, terutama dalam ucapan dan perbuatannya, sedangkan amanah merupakan tanggung jawab seseorang untuk menunaikan pekerjaannya, umumnya sesuai dengan tugas pokok dan fungsinya (tupoksi).

\section{Biografi Singkat Al-Sa'dî dan Karya- Karyanya}

Syaikh Al-Sa'dî atau Ibn Al-Sa'dî memiliki nama lengkap 'Abd Al-Rậmân ibn Nâshir ibn 'Abd Allah ibn Nâshir ibn Hamd Âlu Sa'dî Al-Nâshirî Al-Tamîmî AlHanbalî (1234-1371 H.), ${ }^{22}$ dalam makalah

22 Biografi agak lengkap dan detailnya lihat dalam Rahendra Maya. (2017). "Pemikiran Al-Sa'dî Tentang Konsep Al-Taskhîr”. Al-Tadabbur: Jurnal Ilmu Al Qu'ran dan Tafsir Jurusan Ushuludin Sekolah Tinggi Agama Islam Al Hidayah Bogor. Vol. 02 No.03 Edisi Juli 2017. h. 9-13; dan Rahendra Maya. (2017). "Al-Ahwâl Al-Syakhshiyyah Perspektif Al-Sa'dî: Studi Terhadap Kitab Manhaj Al-Sâlikîn wa Taudhîh Al-Fiqh fi Al- 
ini kemudian disebut dengan dan dinyatakan secara singkat sebagai Al-Sa'dî.

Al-Sa'dî termasuk ulama yang memiliki produktifitas tinggi dalam menulis (tashnîf) dan menyusun karya ilmiah (ta'liff). Karenanya, tidak mengherankan bila ia mampu memproduksi banyak sekali karya ilmiah dalam berbagai disiplin ilmu agama, kini sekitar empat puluhan karyanya telah dicetak. Berikut daftar karya ilmiah Al-Sa'dî secara lengkap: ${ }^{23}$

a. Dalam bidang Al-Qur'ân, Tafsir, dan Ilmunya: Al-Dalâ'il Al-Qur'âniyyah fî anna Al-'Ulûm Al-Nâfi'ah Al-'Ashriyyah Dâkhilah fî̀ Al-Dîn Al-Islâmî, Fawâ id Mustanbathah min Qishshah Yûsuf 'alaihi Al-Salâm, Al-Mawâhib AlRabbâniyyah min Al-Âyât AlQur'âniyyah, Al-Qawâ'id Al- $\underline{H}$ isân li Tafsîr Al-Qur'ân, Taisîr Al-Karîm AlRahmân fî Tafsîr Kalâm Al-Mannân, dan Taisîr Al-Lathîf Al-Mannân fî̀ Khulâshah Tafsîr Al-Qur 'ân.

b. Dalam bidang Hadits: Bahjah Qulûb AlAbrâr wa Qurrah 'Uyûn Al-Akhyâr fî Syarh Jawâmi' Al-Akhbâr.

Dîn". Al-Mashlahah: Jurnal Hukum Islam dan Pranata Sosial Islam. Program Studi Al Ahwal Al-Syakhshiyyah Sekolah Tinggi Agama Islam Al Hidayah Bogor. Vol. 05 No. 10 Edisi Januari 2017. h. 711-712.

${ }^{23}$ Lihat Rahendra Maya. (2017). Pemikiran AlSa'dî Tentang Konsep Al-Ittibâ' Sebagai Core Pendidikan Islam. Edukasi Islami: Bogor: Marwah Indo Media dan STAI Al Hidayah Bogor. h. 11-29. c. Dalam bidang Akidah: Risâlah 'an Ya'jûj wa Ma jîjj, Taudhîh Al-Kâfiyah

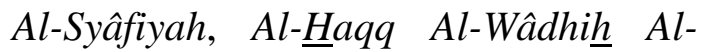
Mubîn fî̀ Syarh Tauhî̀d Al-Anbiyấ ' wa Al-Mursalîn min Al-Kâfiyah AlSyâfiyah, Al-Tanbîhât Al-Lathîfah fî̀ Mâ Ihtawat 'alaihi Al-Wâsithiyyah min AlMabâhits Al-Munîfah, Al-Adillah AlQawâthi' wa Al-Barâhîn fì Ibthâl Ushûl Al-Mulhidîn, Al-Taudhîh wa Al-Bayân li Syajarah Al-Îmân, Al-Durrah AlBahiyyah Syarh Al-Qashîdah Al-Tâ'iyah

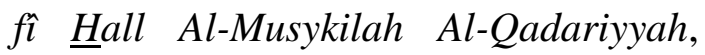

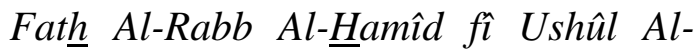
'Aqâ 'id wa Al-Tauhî̀d, Al-Qaul Al-Sadîd fì Maqâshid Al-Taunhîd, dan Su'âl wa Jawâb fì Ahamm Al-Muhimmât.

d. Dalam bidang Fikih dan Ushul Fikih: Risâlah fî Al-Qawâ'id Al-Fiqhiyyah, Manzhûmah fî Ahkâm Al-Fiqh, AlMukhtârât Al-Jaliyyah fî Al-Masâ 'il AlFiqhiyyah, Irsyâd Ûlî Al-Bashâ'ir wa Al-Albâb li Nail Al-Fiqh bi Aqrab AlThuruq wa Aisar Al-Asbâb bi Tharîq Murattab 'alâ Al-Su'âl wa Al-Jawâb (atau Al-Irsyâd ilâ Ma'rifah Al-Ahkâm), Al-Munâzharât Al-Fiqhiyyah, Wujûb AlTa'âwun baina Al-Muslimîn wa Maudhû' Al-Jihâd Al-Dîn̂̀ wa Bayân Kulliyât min Barâhîn Al-Dîn, Risâlah Lathîfah Jâmi'ah fî Ushûl Al-Fiqh AlMuhimmah, Al-Qawâ'id wa Al-Ushûl Al-Jâmi'ah, Al-Furûq wa Al-Taqâsîm

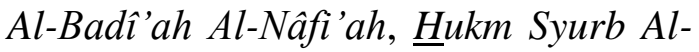




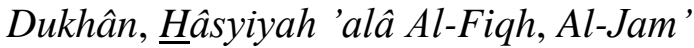
baina al-Inshâf wa Nazhm Ibn 'Abd AlQawî̀, Al-Jihâd fî Sabîl Allah, dan Manhaj Al-Sâlikîn wa Taudhîh Al-Fiqh fì Al-Dîn.

e. Dalam bidang Akhlak dan Adab: Manzhûmah fì Al-Sair ilâ Allah wa AlDâr Al-Âkhirah, Al-Riyâdh Al-Nâdhirah wa Al-Hadâ'iq Al-Nayyirah Al-Zâhirah fî Al-'Aqâ'id wa Al-Funûn AlMutanawwi'ah Al-Fâkhirah, Al-Fatâwâ Al-Sa'diyyah, Majmû' Al-Fawâ'id wa Iqtinâs Al-Awâbid, dan Al-Wasâ'il Al-

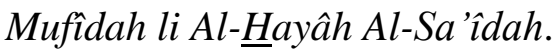

f. Dalam bidang Bahasa Arab: Al-Ta'lîq wa Kasyf Al-Niqâb 'alâ Nazhm Qawâ'id Al-I'râb.

g. Dalam bidang Khuthbah dan Fatwa: Majmî' Al-Khuthab fì Al-Mawâdhî̀'AlNâfi'ah, Al-Fawâkih Al-Syahiyyah fì AlKhuthab Al-Minbariyyah, dan AlKhuthab Al-Minbariyyah 'alâ AlMunâsabât.

h. Dalam bidang Wawasan (Tsaqâfah) Islam: Al-Durrah Al-Mukhtasharah fì Mahâain Dîn Al-Islâm, Tanzîh Al-Dîn

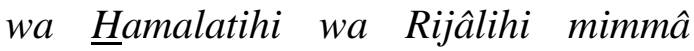
Iftarâhu Al-Qashîmî fî̀ Aghlâlihi,

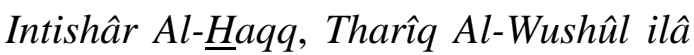
Al-'Ilm Al-Ma'mûl bi Ma'rifah AlQawâ'id wa Al-Dhawâbith wa Al-Ushûl, dan Al-Dîn Al-Shahîh $\underline{h}$ Yahillu Jamî̀ AlMasyâkil i. Yang masih berbentuk manuskrip (makhthûthât): Manzhûmah fî Fadhl Al'Ilm wa Al-Tajarrud lahu, Al-Dalîl (manzhûmah), dan Hâasyiyah 'alâ AlFiqh Istidrâkan 'alâ Jamî' Al-Kutub AlMutadâwilah wa Al-Mu'allafah fî AlMadzhab Al- $\underline{\text { Hanbalî. }}$

\section{Kriteria Pegawai Profesional Perspektif Al-Sa'dî}

Pemikiran bernas Al-Sa'dî tentang kriteria pegawai yang profesional yang dapat ditelusuri dalam karya-karyanya antara lain nampak dalam poin-poin penting sebagai berikut:

\section{Interpretasi (Tafsîr) Al-Sa'dî Terhadap} Q.S. Al-Qashash [28]: 26

Dalam surat Al-Qashash dikisahkan bahwa Musa menolong kedua anak gadis pengembala kambing dengan pertolongan yang menurutnya tidaklah seberapa atau hanya sebagai pertolongan kecil yang sederhana. Setelah gadis tersebut menceritakan kronologis peristiwa yang dialaminya kepada ayahnya, terutama tentang pertolongan yang diberikan Musa, maka ketika sang ayah ingin memberinya upah atas pertolongannya tersebut, serta merta sang gadis mengusulkan agar sebaiknya Musa dijadikan sebagai pegawai (ajîr). ${ }^{24}$ Menurut sang gadis, dalam diri

\footnotetext{
24 Terdapat perbedaan pendapat tentang kedua nama gadis tersebut. Ada yang menyatakan bahwa
} 
Musa terhimpun dua kriteria pegawai yang profesional. Yaitu pegawai yang memiliki kekuatan (qawî) dan keamanahan (amîn) sekaligus.

Kriteria profesionalitas pegawai tersebut dideskripsikan Allah S.W.T. tepatnya dalam Q.S. Al-Qashash [28]: 26 sebagai berikut:

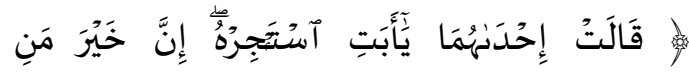

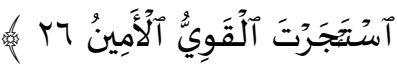

Salah seorang dari kedua (perempuan) itu berkata, "Wahai ayahku! Jadikanlah dia sebagai pekerja (pada kita), sesungguhnya orang yang paling baik yang engkau ambil sebagai pekerja (pada kita) adalah orang yang kuat dan dapat dipercaya.”.

Terkait dengan Q.S. Al-Qashash [28]: 26 di atas, Al-Sa'dî memberikan penafsiran menarik yang teks lengkapnya sebagai berikut: ${ }^{25}$

namanya adalah Shafârayyâ dan Layyâ atau Sarafâ, atau Shafûrayyâ., atau Shafûra, atau Shabûrâ. Demikian pula dengan nama bapaknya. Ada yang berpendapat bahwa namanya adalah Yatrûn, atau Yutsrâ, atau Syu'aib, atau Bairûn ibn Akhî Syu'aib, salah seorang dari kaum Syu'aib, namun yang paling populer adalah Syu'aib. Lihat Jamâl Al-Dîn 'Abd Al-Rahnmân ibn 'Alî ibn Muhammad Al-Jauzî Al-Qurasyî Al-Baghdâdî. (2002). Zâd Al-Masîr fî 'Ilm Al-Tafsîr. Beirut: Al-Maktab Al-Islâmî dan Dâr Ibn Hazm Beirut. h. 1062; dan Muhammad ibn Nâshir Al-Humayyid. (2001). Qishash Al-Nisâ' fì Al-Qur'ân Al-Karîm: Wa Al-Durûs wa Al-'Ibar wa Al-A $\underline{h}$ âm Al-Mustafâdah minhâ. Pakistan: Dâr AlKitâb wa Al-Sunnah. h. 244.

\footnotetext{
${ }^{25}$ Kutipan teks aslinya sebagai berikut:
}

(Salah seorang dari kedua perempuan), yaitu salah satu dari anak gadis tersebut. (Jadikanlah dia sebagai pekerja atau pegawai kita), maksudnya jadikan dan angkatlah ia sebagai pegawaimu yang bertugas menggembala dan memberi makan serta minum kambingkambing peliharaan kita. (Sesungguhnya pegawai yang baik adalah orang yang kuat dan dapat dipercaya), bahwa Musa merupakan orang profesional yang pantas untuk diangkat menjadi pegawai karena memiliki dua kriteria profesionalitas, yaitu kuat dan amanah. Sedangkan -dalam konsep dan realitas- pegawai yang handal adalah yang mampu memiliki dua kriteria profesionalitas tersebut secara sinergis-

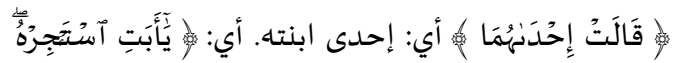

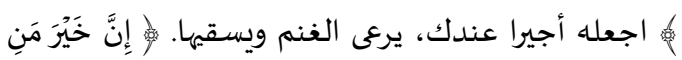

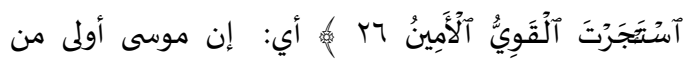

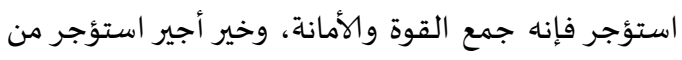

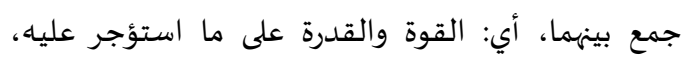

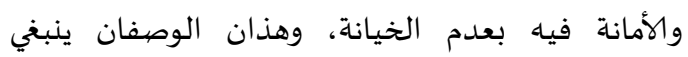

$$
\begin{aligned}
& \text { اعتبارهما في كل من يتولى للإنسان عملا، بإجارة أو غيرها. } \\
& \text { فإن الخلل لا يكون إلا بفقدهما أو فقد إحداهما، وأما }
\end{aligned}
$$

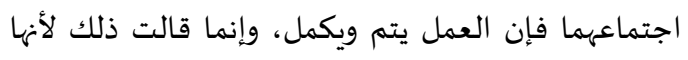

$$
\begin{aligned}
& \text { شاهدت من قوة موسى عند السقي لهما ونشاطه، ما } \\
& \text { عرفت به قوته وشاهدت من أمانته وديانته، وأنه رحمهما } \\
& \text { في حالة لا يرجى نقعهما، وإنما قصهده بذلك وجها الله تعالى. }
\end{aligned}
$$
615. 
organik. Kekuatan tiada lain merupakan kesanggupan untuk melaksanakan suatu pekerjaan dengan baik, sedangkan keamanahan adalah perilaku tidak khianat (culas dan curang) dalam menunaikannya. Kedua kriteria profesionalitas ini wajib diperhatikan oleh pihak mana pun yang hendak mempekerjakan dan mengupah orang lain sebagai pegawainya, untuk berbagai bidang profesi apapun yang legal.

Ketidakberhasilan bahkan kegagalan dalam pekerjaan terjadi karena tidak terpenuhinya kedua kriteria tersebut, atau karena ketiadaan salah satunya. Sebaliknya, jika kedua kriteria profesionalitas tersebut dapat terhimpun secara sinergis-organik, maka pekerjaan menjadi sempurna dan dapat terwujud keberhasilannya. Dari kisah dinyatakan bahwa salah seorang gadis mengemukakan tentang kedua kriteria pegawai tersebut kepada ayahnya, karena ia telah menyaksikan secara langsung tentang kekuatan Musa saat mengambilkan air minum untuk ternak keduanya dan juga dari aktifitas lainnya. Selain mengetahui kekuatan, ia juga mengetahui keamanahan dan sifat agamis Musa, termasuk sifat penyayang terhadap keduanya tanpa mengharap suatu imbalan (modus) tertentu dari keduanya. Pertolongan Musa hanya untuk mengharapkan pahala dari Allah S.W.T. semata.

Kedua gadis mengetahui kekuatan Musa setelah menyaksikan bagaimana ia mengangkat batu besar yang menutupi sumber air seorang diri, padahal biasanya harus diangkat oleh 10 pria dewasa. Sedangkan keamanahannya diketahui dari cara berjalan Musa yang terkadang di depan dan terkadang di belakang mereka secara kondisional dan terutama untuk menghindari prasangka fitnah, karena secara personal-individual ia adalah lelaki normal dan masih berusia muda. ${ }^{26}$

Dalam penafsirannya terhadap Q.S. AlQashash [28]: 26 tersebut dalam karyanya yang lain, Al-Sa'dî menyatakan sebagai pelengkap penafsiran sebelumnya sebagai berikut:

Kedua kriteria profesionalitas ini merupakan faktor utama bagi keberhasilan suatu pekerjaan, apapun profesinya. Semua profesi, baik dalam bidang aparatur pemerintahan, pelayanan publik, industri, atau jenis pekerjaan lainnya yang di dalamnya ada upaya untuk memberikan perlindungan dan evaluasi (manajerial) atas setiap pegawai dan aktivitas profesinya,

26 Lihat Ismâ'̂̂l ibn 'Umar ibn Katsîr AlQurasyî Al-Dimasyqî. (1999). Tafsîr Al-Qur'ân Al'Azhîm. ed. Sâmî ibn Muhammad Al-Salâmah. Riyadh: Dâr Thayyibah. Vol. 6. h. 229; Al-Husain ibn Mas'ûd Al-Baghawî. (1411 H.). Ma'âlim AlTanzîl. ed. Muhammad 'Abd Allah Al-Namr, 'Utsmân Jum'ah Dhumairiyyah, dan Sulaimân Muslim Al-Harasy. Riyadh: Dâr Thayyibah. Vol. 6. h. 202; dan Muhammad ibn 'Alî ibn Muhammad AlSyaukânî. (2007). Fath Al-Qadîr: Al-Jâmi' baina Fannai Al-Riwâyah wa Al-Dirâyah min 'Ilm AlTafsîr. ed. Yûsuf Al-Ghûsy. Beirut: Dâr AlMa'rifah. h. 1098. 
maka memerlukan sinergitas dari kedua kriteria profesionalitas tersebut. Pertama, berlandaskan kekuatan yang memicu kemampuan untuk menyelesaikan pekerjaan yang digeluti sesuai dengan bidang profesinya. Kedua, berdasarkan keamanahan yang memacu kejujuran dalam penunaiannya. Bila demikian halnya, pekerjaan diharapkan akan selesai dengan sempurna dan hasilnya pun akan sesuai dengan standar yang menjadi ekspektasi terhadapnya. Sebaliknya, bila kedua kriteria tersebut tidak terpenuhi, baik salah satu maupun keduanya, maka pekerjaan akan gagal atau selesai dengan tidak sempurna (di bawah ekspektasi dan tidak sesuai target yang telah direncanakan). ${ }^{27}$

Oleh karena itu, kriteria utama dan standar terpenting dalam memilih seorang pegawai atau pekerja profesional hendaklah didasarkan kepada kekuatan dan keamanahannya.

\footnotetext{
${ }^{27}$ Kutipan teks aslinya sebagai berikut:

هذان وصفان بهما تمام الأعمال كلها، فكل عمل من الولايات أو من

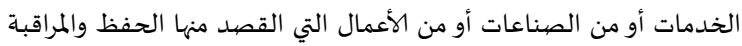
على العمال والأعمال إذا جمع الإنسان الوصفين، أن يكون قويا على ذلك

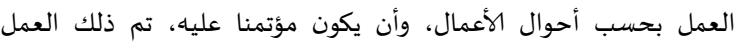
وحصل مقصوده وثمرته، والخلل والنقص سببه الإنحلال بهما أو بأحدهما.

Lihat pula 'Abd Al-Rahmân ibn Nâshir Al-Sa'dî. (1992). "Taisîr Al-Lathîf Al-Mannân fî̀ Khulâshah Tafsîr Al-Qur'ân”. Dalam Al-Majmû'ah Al-Kâmilah li Mu'allafât Al-Syaikh 'Abd Al-Rahmân ibn Nâshir AlSa'dî: Al-Juz' Al-Tsâmin. Unaizah: Markaz Shâlih ibn Shâlih Al-Tsaqâfî. h. 370.
}

Dalam Q.S. Yûsuf [12]: 54 yang dapat dianggap sebagai deskripsi penguat bagi Q.S. Al-Qashash [28]: 26 tentang kriteria pegawai yang profesional, Allah S.W.T. juga berfirman:

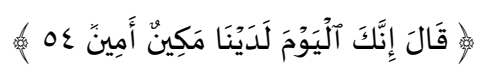

Dia (raja) berkata, "Sesungguhnya kamu (mulai) hari ini menjadi seorang yang berkedudukan tinggi di lingkungan kami dan dipercaya.".

Dalam kitab tafsirnya ketika menafsirkan Q.S. Yûsuf [12]: 54 tersebut, Al-Sa'dî menyatakan:

(Seorang yang berkedudukan tinggi), yaitu orang yang telah teruji kompetensi dan diakui profesionalitasnya sehingga layak diserahi jabatan tinggi (mutamakkin). (Dan dipercaya), maksudnya dipercaya untuk memegang pelbagai kerahasiaan (amîn 'alâ al-asrâr). ${ }^{28}$

Berdasarkan penafsiran dan interpretasi terhadap Q.S. Al-Qashash [28]: 26 dan juga Q.S. Yûsuf [12]: 54, dapat dinyatakan bahwa kriteria utama bagi profesionalitas pegawai menurut Al-Sa'dî adalah:

a. Kriteria kekuatan atau memiliki karakter kuat.

b. Kriteria kemanahan atau memiliki karakter amanah.

28 'Abd Al-Rahnmân ibn Nâshir Al-Sa'dî. (2000). h. 401 . 
Penjelasan (Syarh ) Al-Sa'dî Terhadap

Hadits Al-Mu'min Al-Qawî Khairun wa Ahabbu ilâ Allah (H.R. Muslim)

Hadits yang dimaksud adalah sabda Rasulullah S.A.W. yang teks lengkapnya sebagai berikut:

(( المؤمن القوي خيروأحب إلى الله من المؤمن الضعيف، وفي كل خير، احرص على ما ينفعك، واستعن بالله، ولا تعجز، وإن أصابك شيء فلا تقل: لو أني فعلت كذا كان كذا وكذا، ولكن

قل: قدر الله وما شاء فعل، فإن لو تفتح عمل الشيطان )

Seorang Mukmin yang kuat adalah orang yang lebih baik dan lebih dicintai oleh Allah S.W.T. dari pada seorang mukmin yang lemah. Namun pada masing-masing dari keduanya terdapat kebaikannya tersendiri. Antusiaslah dalam menggapai halhal yang bermanfaat bagimu, mintalah selalu pertolongan kepada Allah S.W.T., dan jangan berlaku lemah. Jika engkau tertimpa suatu musibah, maka janganlah berkata, "Seandainya akau berbuat begini tentu hasilnya akan begini!”. Namun katakanlah, "Demikianlah yang telah Allah tentukan, dan apa yang dikehendaki-Nya pastilah terjadi.". Sesungguhnya ungkapan pengandaian tersebut akan mengundang celah godaan bagi upaya setan terhadapnya. (H.R. Muslim)

Ketika memberikan penjelasan (syar $\underline{h})$ terhadap hadits tersebut, Al-Sa'dî menyatakan sebagai berikut: ${ }^{29}$

\footnotetext{
${ }^{29}$ Kutipan teks aslinya sebagai berikut:
}

Ketika Nabi Muhammad S.A.W. menjelaskan tentang adanya perbedaan keunggulan di antara kaum Mukminin, antara yang kuat dengan yang lemah, maka hal ini dapat dipahami secara salah sebagai bentuk diskrminasi terhadap pihak yang kurang utama, yaitu kaum yang lemah. Maka sabda selanjutnya, "Namun pada masing-masing dari keduanya terdapat kebaikannya tersendiri.", hal ini memberikan faedah yang sangat penting bahwa siapa saja yang hendak memilih dan memilah suatu keunggulan, baik berdasarkan identitas diri seseorang, jenis kelamin, maupun jenis profesinya, maka ia pun harus mendeskripsikan aspek dan jenis keunggulannya tersebut. Di samping itu, harus dijelaskan pula aspek yang menjadi titik temu atau kesamaan antar keduanya, baik yang diklasifikasi sebagai pihak yang unggul maupun yang diklaim sebagai pihak yang kurang unggul. Standar ini berlaku pula

$$
\begin{aligned}
& \text { ولما فاضل النبي صلى الله عليه وسلم بين المؤمنين قويهم وضعيفهم } \\
& \text { خشي من توهم القدح في المفضول، فقال: (( وفي كل خير ))، وفي } \\
& \text { هذا الاحتراز فائدة نفيسة، وهي على أن من فاضل بين الأشخاص } \\
& \text { أو الأجناس أو الأعمال أن يذكر وجه التفضيل وجهة التفضيل. }
\end{aligned}
$$

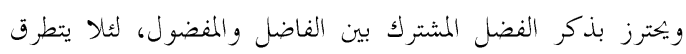

$$
\begin{aligned}
& \text { القدح إلى المفضول. و كذلك في الجانب الآخر إذا ذكرت مراتب }
\end{aligned}
$$

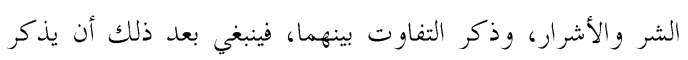

$$
\begin{aligned}
& \text { القدر المشترك بينهما من أسباب الخير أو الشر. وهذا كثير } \\
& \text { في الكتاب والسنة. }
\end{aligned}
$$

Lihat 'Abd Al-Rahmân ibn Nâshir Al-Sa'dî. (1424 H.). Bahjah Qulûb Al-Abrâr wa Qurrah 'Uyûn Al-Akhyâr fî Syarh Jawâmi' Al-Akhbâr. ed. Muhammad ibn 'Abd Al-Jawwâd Al-Shâwî. Jeddah: Dâr Al-Hudâh. h. 41. 
ketika menyebutkan kelemahan dan pihakpihak yang dianggap memiliki kelemahan. Setelah menerangkan aspek perbedaan keduanya, maka kemukakan pula titik temu atau kesamaan antar keduanya. Yaitu dengan menyebutkan faktor-faktor keunggulan dan kelemahan dari masing-masingnya. Metode seperti inilah yang banyak diungkap dalam Al-Qur'an dan Al-Sunnah.

Selanjutnya Al-Sa'dî menjelaskan beberapa poin penting dari hadits tersebut yang dapat dirangkum sebagai berikut:

Pertama, "Antusiaslah dalam menggapai hal-hal yang bermanfaat bagimu", yaitu mencakup hal-hal yang bermanfaat dalam masalah agama atau aspek maknawi-ukhrawi dan dalam masalah duniawi atau aspek duniawi-inderawi.

Aspek maknawi-ukhrawi berporos pada dua pilar, yaitu ilmu yang bermanfaat ('ilm nâfi') dan amal shalih ('amal shâlih $)$. Sedangkan aspek duniawi-inderawi berkaitan dengan kemampuan dalam mencari rezeki dan keahlian dalam bidang profesi tertentu.

Kedua, "Mintalah selalu pertolongan kepada Allah S.W.T.", yaitu dengan beriman kepada ketentuan dan takdir Allah S.W.T., perintah untuk bertawakkal hanya kepadaNya dengan selalu bersandar secara totalitas kepada daya upaya dan kekuatan-Nya, dan dengan menguatkan keyakinan akan keberhasilan hidup yang dianugerahkan-Nya.

Al-Sa'dî juga mengingatkan bahwa meminta pertolongan kepada Allah S.W.T. dapat dilakukan antara lain dengan memaksimalkan potensi waktu pagi dan sore hari serta dengan mengoptimalkan penggalan waktu di malam hari -tepatnya tengah malam atau sepertiga malam yang terakhir-, spesifiknya untuk membekali diri dengan kebaikan ukhrawi dan dengan tidak lupa untuk membekali diri dengan kekuatan duniawi berdasarkan sebab-sebabnya secara maksimal. $^{30}$

Ketiga, "Dan jangan berlaku lemah.", adalah penguatan dari perintah untuk selalu bersungguh-sungguh, rajin, dan antusias, baik dalam niat, motivasi, operasional kerja, maupun dalam memenej atau mengawal kesuksesannya (al-amr bi al-jidd wa al-ijtihâd wa al-hirsh 'alaihi, niyyatan wa himmatan wa fi'lan wa tadbîran). ${ }^{31}$

Hadits di atas memberikan tuntunan kepada kaum Muslimin untuk membina dan mengkader umat menjadi sumber daya Muslim yang kuat lagi kreatif dan inovatif (al-mu'min al-qawî al-fa'âl). Yaitu seorang

${ }^{30}$ Lihat 'Abd Al-Rahmân ibn Nâshir Al-Sa'dî. (1420 H.). Nûr Al-Bashâ'ir wa Al-Albâb fì Ahkâm Al-'Ibâdât wa Al-Mu'âmalât wa Al- $\underline{H} u q u \hat{q}$ wa AlÂdâb. ed. Khâlid ibn 'Utsmân Al-Sabt. Damam: Dâr Ibn Al-Jauzî. h. 73.

${ }^{31}$ Lihat 'Abd Al-Rahmân ibn Nâshir Al-Sa'dî. (1424 H.). h. 42-44. 
Mukmin yang komitmen kepada ajaran agamanya, berprestasi dalam hidupnya, dan menonjol dalam bidang kerjanya (al-mu'min al-multazim bi dînihi, al-nâjih fì hayâtihi, almutafawwiq fí 'amalihi). Ia pun merupakan seorang Muslim yang dengan tegas menolak untuk hidup dalam kungkungan kemalasan dan belenggu ketidakberdayaan (al-kasal wa al-khumûl) serta dalam kurungan stagnasi, tanpa ada penambahan wawasan dan kreatifitas yang dihasilkan. ${ }^{32}$

Menurut pendapat ulama lain, kekuatan yang dimaksud dalam hadits adalah kekuatan dalam agama, fisik lahiriah, jiwa, dan akal rasionalitas atau intelektualitas, ${ }^{33}$ atau yang kuat fisik dan psikis serta memiliki tekad yang kuat. ${ }^{34}$

Sedangkan menurut murid Al-Sa'dî sendiri, Muhammad ibn Shâlih Al'Utsaimîn, ia menekankan bahwa yang dimaksud dengan kekuatan tiada lain adalah kekuatan iman yang akan menuntun seseorang memiliki kemampuan untuk melaksanakan hal-hal yang diwajibkan Allah S.W.T. kepadanya dan mengerjakan berbagai hal yang dianjurkan sebagai tambahan kesempurnaannya. ${ }^{35}$

Namun dalam kesempatan lainnya ketika menjelaskan kitab Al-Siyâsah AlSyar'iyyah karya Ibn Taimiyyah, Al'Utsaimîn mengokohkan pernyataan Ibn Taimiyyah bahwa kekuatan yang dimaksud adalah bersifat kondisional-proporsional sesuai dengan kebutuhan, termasuk dalam bentuk profesi dan jenis pekerjaan tertentu, ${ }^{36}$ tidak semata-mata karena keimanan yang memang harus tetap menjadi landasan dasar.

Dari penjelasan (syarh ) Al-Sa'dî terhadap hadits Al-Mu'min Al-Qawî Khairun wa A $\underline{h a b b u}$ ilâ Allah dapat ditarik kesimpulan bahwa kekuatan yang menjadi standar kriteria bagi pegawai profesional adalah kekuatan yang dapat memberikan manfaat, yaitu kekuatan maknawi-ukhrawi berupa ilmu dan amal serta kekuatan duniawi-inderawi berupa keahlian tertentu yang sesuai dengan bidang profesi yang digeluti dan diamanahkan kepadanya.

35 Lihat Muhammad ibn Shâlih Al-'Utsaimîn. (1425 H.). Syarh Riyâdh Al-Shâlihîn min Kalâm Sayyid Al-Mursalîn. Riyadh: Madâr Al-Wathan. Vol. 2. h. 77.

${ }^{36}$ Lihat Muhammad ibn Shâlih Al-'Utsaimîn. (2004). Syarh Kitâb Al-Siyâsah Al-Syar'iyyah li Syaikh Al-Islâm Ibn Taimiyyah. Oman: Al-Dâr Al'Utsmâniyyah dan Dâr Ibn Hazm Beirut. h. 43-46. 
Penjelasan (Syarh ) Al-Sa'dî Terhadap

Hadits Innamâ Al-Nâs ka Al-Ibil Al-

Mi'ah (H.R. Al-Bukhârî dan Muslim)

Dalam hadits yang dimaksud, Rasulullah S.A.W. bersabda:

(( إنما الناس كالإبل المائة، لا تكاد تجد فيها راحلة )( )

Sesungguhnya perumpamaan (analogi) manusia itu ibarat sekumpulan unta yang berjumlah seratus ekor, dimana engkau hampir saja mengalami kesualitan untuk menemukan salah satunya sebagai tunggangan (yang ideal). (H.R. Al-Bukhârî dan Muslim)

Berkaitan dengan hadits tersebut di atas, Al-Sa'dî memberikan penjelasan (syarh) menawan sebagai berikut: ${ }^{37}$

Hadits ini berisi dua hal yang sangat penting, yaitu kabar yang valid dan

\footnotetext{
${ }^{37}$ Kutipan teks aslinya sebagai berikut: هذا الحديث مشتمل على خبر صادق وإرشاد نافع. أما الخبر: فإنه صلى الله عليه وسلم أخبر أن النقص شامل لأكثر الناس، وأن الكامل -أو مقارب الكمال- فيهم قليل، كالإبل المائة تستكثرها. فإذا أردت منها راحلة تصلح للحمل فهل والركوب والذهاب والإياب، لم تكد تجدها. وهكذا الناس كثير،

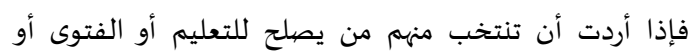

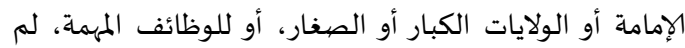
تكد تجد من يقوم بتلك الوظيفة قياما صالحا، وهذا هو الواقع. فإن الإنسان ظلوم جهول، والظلم والجهل سبب لهن للنقص، وهي مانعة من الكمال والتكميل. وأما الإرشاد: فإن مضمون هذا الخبر إرشاد منه صلى الله عليه وسلم إلى أن ينبخي لمجموع الأمة أن يسعوا ويجتهدوا في تأهيل الرجال الذين يصلحون للقيام بالمهمات، والأمور الكلية العامة النفع.
}

Lihat 'Abd Al-Rahmân ibn Nâshir Al-Sa'dî. (1424 H.). h. 255. sekaligus sebagai tuntunan yang bermanfaat.

Sebagai kabar yang valid, Rasulullah S.A.W. menginformasikan bahwa kekurangan merupakan hal lumrah yang dimiliki oleh mayoritas orang. Sedangkan kesempurnaan -atau mendekati sempurnasangat jarang dimiliki; ibarat kumpulan 100 unta, yang terbaik hanyalah satu saja, baik digunakan sebagai tunggangan maupun untuk alat transportasi lainnya. Begitu pula dalam realitas manusia. Karena itu, ketika engkau hendak memilih yang terbaik dari mereka, baik dalam bidang pendidikan, fatwa, kepemimpinan dalam skala minor maupun mayor, atau dalam profesi-profesi lainnya yang penting, maka sedikit engkau temukan orang yang dapat mengerjakannya dengan baik. Ini merupakan keniscayaan realitas. Manusia memiliki karakter dasar yang selalu melekat padanya, yaitu banyak berbuat aniaya dan sering dihinggapi kebodohan. Keduanya merupakan faktor penyebab munculnya kekurangan, yang secara aksiomatis menjadi penghalang bagi kesempurnaan dan proses keparipurnaan.

Sedangkan sebagai tuntunan yang bermanfaat, maka makna substansial yang terkandung dalam hadits merupakan tuntunan Rasulullah S.A.W. bagi setiap umat untuk bersungguh-sungguh dan bekerja keras untuk mencetak kader-kader yang memiliki kelayakan kompetensi dan 
profesionalitas untuk mengemban pelbagai tugas dan beragam tanggung jawab yang bermanfaat bagi kemashlahatan umat.

Di akhir penjelasannya (syarh terhadap hadits di atas, Al-Sa'dî memberikan pernyataan penutup sebagai berikut: ${ }^{38}$

فالوظائف الدينية والدنيوية والأعمال الكلية، لابد للناس منها، ولا تتم مصلحتهم إلا بها، وهي لا تتم إلا بأن يتولاها الأكفاء والأمناء، وذلك يستدعى السعي في تحصيل هذه الأوصاف بحسب

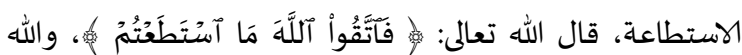

Bidang profesi kerja, baik berkaitan dengan aspek ukhrawi maupun duniawi serta aktifitas kerja lainnya secara general, pastilah membutuhkan pegawai atau tenaga kerja (sumber daya manusia, men and peoples) di dalamnya. Kemashlahatan mereka tidak mungkin terealisasi kecuali bila hal tersebut terpenuhi. Yaitu akan sempurna bila pegawai yang diangkat adalah para pegawai yang kompeten dan amanah. Oleh karena itu, dituntut kerja keras secara optimal untuk mendapatkan kriteri pegawai yang profesional tersebut, sebagaimana Allah S.W.T. berfirman, "Maka bertakwalah kalian kepada Allah dengan seoptimal kemampuan." (Q.S. AlTaghâbun [64]: 16). Wallahu a'lam.

38 'Abd Al-Rahmmân ibn Nâshir Al-Sa'dî. (1424 H.). h. 256.
Al-Sa'dî dalam menjelaskan (syarh hadits Innamâ Al-Nâs ka Al-Ibil Al-Mi'ah mengaitkannya dengan kriteria pegawai profesional yang kuat dan amanah. Menurutnya, untuk memperoleh kedua kriteria tersebut dalam diri seseorang tidaklah mudah, namun bukan berarti sebuah kemustahilan. Yang dibutuhkan adalah upaya maksimal dan kerja keras dalam mengkader dan membentuk profesionalitas kerja tersebut.

\section{Kajian Al-Sa'dî Tentang Karakter} Keamanahan (Amânah) dan Kejujuran $(\text { Shidq })^{39}$

Al-Sa'dî secara tegas menyatakan bahwa Allah S.W.T. memerintahkan kejujuran dan untuk menunaikan amanat (al-shidq wa adâ' al-amânât) dalam cukup banyak ayat dan hadits. Hal ini mencakup penunaian amanat dalam kepemimpinan baik yang berskala mikro maupun makro, termasuk amanat harta benda, hak-hak yang harus diberikan, dan yang terkait dengan kerahasiaan serta hal lainnya. ${ }^{40}$ Termasuk tentunya adalah hak-hak dalam pekerjaan dan bidang profesi yang diamanahkan.

${ }^{39}$ Lihat 'Abd Al-Rahmân ibn Nâshir Al-Sa'dî. (1982). Al-Riyâdh Al-Nâdhirah wa Al- $\underline{\text { Hadâ } i q ~ A l-~}$ Nayyirah Al-Zâhirah fì Al-'Aqâ'id wa Al-Funûn AlMutanawwi'ah Al-Fâkhirah. Riyadh: Maktabah AlMa’ârif. h. 26-28.'

40 'Abd Al-Raḥmân ibn Nâshir Al-Sa'dî. (1982). h. 26. 
Pembuat syariat -secara mutlak adalah Allah S.W.T. dan Rasulullah S.A.W. secara terkait- menganjurkan untuk berlaku jujur dan amanat adalah karena sifat (jujur dan amanat) tersebut merupakan pengantar (titik tolak) sekaligus sebagai penggerak bagi munculnya akhlak baik lainnya (muqaddimah al-akhlâq al-jamîlah wa alda'iyah ilaihâ). ${ }^{41}$

Hal ini dilandaskan kepada hadits Rasulullah S.A.W. yang bersabda sebagai berikut:

(( عليكم بالصدق، فإن الصدق يهدي إلى البر، وإن البر يهدي إلى الجنة، وما يزال الرجل يصدق ويتحرى الصدق حتى يكتب عند الله صديقا، وإيكم والكذب، فإن الكذب يهدي إلى الفجور، وإن والفجور يهدي إلى النار، وما يزال الرجل يكذب ويتحرى

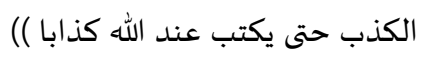

Hendaklah kalian selalu berlaku jujur, karena kejujuran membawa kepada kebaikan, dan kebaikan akan mengantarkan seseorang ke Surga. Apabila seorang selalu berlaku jujur dan tetap memilih kejujuran, maka ia akan dicatat di sisi Allah S.W.T. sebagai orang yang jujur. Sebaliknya, jauhilah oleh kalian berbuat dusta, karena kedustaan membawa kepada kejahatan, dan kejahatan mengantarkan seseorang ke Neraka. Jika seseoang senantiasa berdusta dan tetap memilih kedustaan, maka ia akan dicatat di sisi Allah S.W.T. sebagai

41 'Abd Al-Rahmân ibn Nâshir Al-Sa'dî. (1982). h. 26-27.' pendusta (pembohong). (H.R. Al-Bukhârî,

\section{Muslim, dan lainnya)}

Al-Sa'dî mengidentifikasi kejujuran (shidq) sebagai perlambang keislaman ('unwân Al-Islâm), barometer keimanan (mîzân al-îmân), asas beragama (uss aldîn), dan tanda kesempurnaan sifat pelakunya ('alâmah 'alâ kamâl almuttashif bihi). Kejujuran juga memiliki kedudukan tinggi, baik dalam agama maupun dalam perspektif keduniawian, yaitu sebagai manifestasi keikhlashan yang jujur (sharîh al-ikhlâsh), dimana ikhlash dan kejujuran adalah keselarasan antar perilaku lahir dengan keadaan batin seorang yang ikhlash. Kejujuran akan menuntun seeorang mencapai derajat ketinggian hamba-hamba yang mulia dan menghindarkannya dari berbagai keburukan. Kejujuran dan keamanahan (alshidq wa adâ' al-amânah) adalah faktor penyubur datangnya keberkahan dan ketenangan (al-barakah wa al-tuma'nînah) serta menjadikan pemiliknya menjadi seorang yang kredibel, baik di hadapan Allah S.W.T. maupun di hadapan hambahamba-Nya, $^{42}$ serta berbagai kebaikan lainnya yang sangat banyak lagi beragam.

Sebagai tambahan dan pelengkap pembahasannya tentang kriteria pegawai profesional yang kuat dan amanah, Al-

42 'Abd Al-Raḥmân ibn Nâshir Al-Sa'dî. (1982). h. 27. 
Sa'dî memberikan penekanan secara tegas bahwa karakter keamanahan (amânah) yang dipadu dengan kejujuran (shidq) merupakan pengantar atau titik tolak dan penggerak bagi munculnya karakter atau akhlak baik lainnya. Hal ini memberikan indikasi tentang urgen dan pentingnya keamanahan plus kejujuran sebagai kriteria utama bagi pegawai yang profesional.

\section{KESIMPULAN}

Pemikiran Al-Sa'dî tentang kriteria pegawai profesional terlihat jelas dalam interpretasinya (tafsîr) terhadap Q.S. AlQashash [28]: 26, penjelasan (syar $\underline{h}$ ) terhadap beberapa hadits terkait, dan kajiannya terhadap karakter atau sifat keamanahan (amânah) dan kejujuran (shidq). Pada akhirnya Al-Sa'dî menyimpulkan bahwa kriteria pegawai profesional adalah pegawai yang memiliki sifat atau karakter kuat (quwwah) dan amanah (amânah) plus jujur (shidq).

Kekuatan (quwwah) dalam profesi kerja yang dimaksud Al-Sa'dî adalah kekuatan yang bersifat menyeluruh, tidak hanya mencakup kekuatan iman, namun meliputi kekuatan fisik lahiriah, jiwa, dan akal rasionalitas atau intelektualitas, serta kekuatan psikis atau mental psikologis.

Al-Sa'dî memaknai keamanahan (amânah) dalam bekerja sebagai tanggung jawab yang memacu kejujuran dalam penunaiannya. Sedangkan kejujuran (shidq) bila dibedakan dengan keamanahan menurut Al-Sa'dî berarti integritas kepribadianpersonal yang menjadi pengantar (titik tolak) sekaligus sebagai penggerak bagi munculnya akhlak baik lainnya (muqaddimah al-akhlâq al-jamîlah wa al-da'iyah ilaihâ).

Demikian kriteria pegawai yang profesional berdasarkan pemikiran dan menurut perspektif Al-Sa'dî. Wallahu a'lam bi al-shawâb.

\section{DAFTAR PUSTAKA}

'Abd Al-'Azîz, Hisyâm Mushthafâ. et.al. 2005. "Shina'ah Al-Hadaf", t.t.p: t.p.

'Abd Al-Bâqî, Muhammad Fu'âd. (1988). "Al-Mu'jam Al-Mufahras li Alfâzh Al-Qur'ân Al-Karîm”. Beirut: Dâr Al-Jîl.

Ashfahânî, Al-Râghib Al-. 2001. “AlMufradât fì Gharîb Al-Qur 'ân’, ed. Muhammad Khalîl 'Aitânî. Beirut: Dâr Al-Ma'rifah.

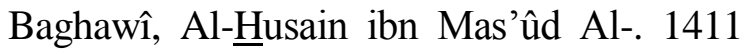

H. "Ma'âlim Al-Tanzîl”, ed. Muhammad 'Abd Allah Al-Namr, 'Utsmân Jum'ah Dhumairiyyah, dan Sulaimân Muslim Al- $\underline{\text { Harasy. Riyadh: }}$ Dâr Thayyibah.

Baghdâdî, Jamâl Al-Dîn 'Abd Al-Raḥmân ibn 'Alî ibn Muhammad Al-Jauzî AlQurasyî Al-. 2002. “Zâd Al-Masîr fì 
'Ilm Al-Tafsîr'. Beirut: Al-Maktab

Al-Islâmî dan Dâr Ibn Hazm Beirut.

Departemen Pendidikan Nasional. 2012.

Kamus Besar Bahasa Indonesia

Pusat Bahasa: Edisi Keempat.

Jakarta: PT Gramedia Pustaka Utama.

Dimasyqî, Ismâ'îl ibn 'Umar ibn Katsîr Al-

Qurasyî Al-. 1999. “Tafsîr Al-Qur'ân

Al-'Azhîm”, ed. Sâmî ibn Muhammad

Al-Salâmah. Riyadh: Dâr Thayyibah.

Fachrudin, Fachri. 2013. "Fikih Bekerja".

Al-Mashlahah: Jurnal Hukum Islam dan Pranata Sosial Islam. Program Studi Ahwal Syakhshiyah Jurusan Hukum Islam Sekolah Tinggi Agama Islam Al Hidayah Bogor. Vol. 01 No. 01 Edisi Januari 2013.

Furaih, Mâzin ibn 'Abd Al-Karîm Al-. 2004. "Al-Râ'id: Durûs fì AlTarbiyah wa Al-Da'wah", Jeddah: Dâr Al-Andalus Al-Khadhrâ‘.

Haqqî, Ahmad Mu'âdz. 1414 H. "Al-

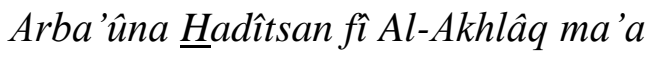
Syarhihâ". Riyadh: Dâr Thuwaiq.

Hâzimî, Khâlid ibn Hâmid Al-. 2000. "Ushûl Al-Tarbiyah Al-Islâmiyyah", Riyadh: Dâr'Âlam Al-Kutub.

Hilâlî, Salîm ibn 'Îd Al-. 1997. "Bahjah AlNâzhirîn Syarh Riyâdh Al-Shâlihîin", Beirut: Dâr Ibn Al-Jauzî.

Humayyid, Muhammad ibn Nâshir Al-. 2001. "Qishash Al-Nisâ' fì Al-Qur'ân Al-Karîm: Wa Al-Durûs wa Al-'Ibar wa Al-Ahkâm Al-Mustafâdah minhâ".

Pakistan: Dâr Al-Kitâb wa Al-Sunnah.

Ibn Humaid, Shâlih ibn 'Abd Allah. et.al. 2004. 'Mausû'ah Nadhrah Al-Na'îm

fì Makârim Akhlâq Al-Rasûl Al-

Karîm”. Jeddah: Dâr Al-Wasîlah.

Jauziyyah, Muhammad ibn Abî Bakr ibn Qayyim Al-. 2003. "Madârij Al-

Sâlikîn baina Manâzil Iyyâka

Na'budu wa Iyyâka Nasta'în", ed.

'Imâd 'Âmir. Kairo: Dâr Al- $\underline{\text { Hadîts. }}$

Khin, Mushthafa Sa'id Al-. et.al. 1987.

"Nuzhah Al-Muttaqîn: Syarh Riyâdh Al-Shâlihîn min Kalâm Sayyid AlMursalin”, Beirut: Mu'assasah AlRisâlah.

Maidânî, 'Abd Al-Rậmân ㅍabanakah Al-. (1999). "Al-Akhlâq Al-Islâmiyyah wa Ususuhâ". Jeddah: Dâr Al-Basyîr dan Dâr Al-Qalam Damaskus.

Majma' Al-Lughah Al-'Arabiyyah Jumhûriyyah Mishr Al-'Arabiyyah. 2012. “Al-Mu'jam Al-Wajîz”, Mesir: Maktabah Al-Syurûq Al-Dauliyyah. Maya, Rahendra. 2015. "Perspektif Islam Tentang Konsep "Life Skills Education". Edukasi Islami: Jurnal Pendidikan Islam. Program Studi Pendidikan Agama Islam Jurusan Tarbiyah Sekolah Tinggi Agama Islam (STAI) Al Hidayah Bogor. Vol. 04 No. 07 Edisi Januari 2015.

Maya, Rahendra. 2017. "Al-A $\underline{h w a ̂ l ~ A l-~}$ Syakhshiyyah" Perspektif Al-Sa'dî: 
Studi Terhadap Kitab Manhaj Al-

Sâlikîn wa Taudhîh Al-Fiqh fî̀ Al-

Dîn". Al-Mashlahah: Jurnal Hukum

Islam dan Pranata Sosial

Islam.ProgramStudiAl-AhwalAl-Sya

khshiyyah Jurusan Hukum Islam

Sekolah Tinggi Agama Islam (STAI)

Al Hidayah Bogor. Vol. 05 No. 10

Edisi Januari 2017.

Maya, Rahendra. 2017. "Pemikiran Al-

Sa'dî Tentang Konsep Al-Taskhîr',

Al-Tadabbur: Jurnal Ilmu Al-

Qurean dan Tafsir. Program Studi

Ilmu Al-Qurean dan Tafsir Jurusan

Ushuludin Sekolah Tinggi Agama

Islam (STAI) Al Hidayah Bogor. Vol. 02 No. 03 Edisi Juli 2017.

Maya, Rahendra. 2017. "Pemikiran Al-

Sa'dî Tentang Konsep Al-Ittibâ'

Sebagai Core Pendidikan Islam".

Edukasi Islami: Bogor: Marwah Indo

Media dan STAI Al Hidayah Bogor.

Mishri, Mahmud Al-. 2011. "Ensiklopedia

Akhlak Muhammad S.A.W.", Jakarta:

Pena Pundi Aksara.

Mishrî. Muhammad ibn Mukrim ibn Manzhûr Al-Afrîqî Al-. 2011. "Lisân Al-'Arab”. Beirut: Dâr Shâdir.

Ramayulis, 2013. "Profesi \& Etika

Keguruan”. Jakarta: Kalam Mulia.

Sa'dî, 'Abd Al-Raḥmân ibn Nâshir Al-.

1982. "Al-Riyâdh Al-Nâdhirah wa Al-

Hadâ'iq Al-Nayyirah Al-Zâhirah fî Al-'Aqâ'id wa Al-Funûn Al-
Mutanawwi'ah

Al-Fâkhirah”.

Riyadh: Maktabah Al-Ma'ârif.

Sa'dî, 'Abd Al-Rahmmân ibn Nâshir Al-.

1420 H. "Nûr Al-Bashâ'ir wa Al-

Albâb fî Ahkâm Al-'Ibâdât wa Al-

Mu'âmalât wa Al- $\underline{H} u q \hat{u} q$ wa Al-

Âdâb”, ed. Khâlid ibn 'Utsmân Al-

Sabt. Damam: Dâr Ibn Al-Jauzî.

Sa'dî, 'Abd Al-Rahmân ibn Nâshir Al-. 2000. "Taisîr Al-Karîm Al-Raḥmân fî

Tafsîr Kalâm Al-Mannân”, ed. 'Abd

Al-Raḩmân ibn Mu'allâ Al-

Luwaihiq. Beirut: Mu'assasah Al-

Risâlah.

Sa'dî, 'Abd Al-Raḥmân ibn Nâshir Al-. 1992. "Taisîr Al-Lathîf Al-Mannân fî̀ Khulâshah Tafsîr Al-Qur‘ân”. Dalam "Al-Majmîn'ah Al-Kâmilah li Mu'allafât Al-Syaikh 'Abd AlRahmân ibn Nâshir Al-Sa'dî: Al-Juz ' Al-Tsâmin”. Unaizah: Markaz Shâlih ibn Shâlih Al-Tsaqâfî.

Sa'dî, 'Abd Al-Rahmân ibn Nâshir Al-. 1424 H. "Bahjah Qulûb Al-Abrâr wa Qurrah 'Uyûn Al-Akhyâr fî Syarh Jawâmi' Al-Akhbâr". ed. Muhammad ibn 'Abd Al-Jawwâd Al-Shâwî. Jeddah: Dâr Al-Hudâh.

Shiddieq, Umay M. Dja'far. 2016. “Mushaf Tafhim Al-Qur'an Daarul 'Amal'. Sukabumi: Yayasan Pendidikan dan Sosial Islam Daarul 'Amal.

Syâfi'î, Husain Muhammad Fahmî Al-. 2008. “Al-Dalîl Al-Mufahras li Alfâzh 
Al-Qur'ân Al-Karîm”. Kairo: Dâr alSalâm.

Syaukânî, Muhammad ibn 'Alî ibn Muhammad Al-. 2007. "Fath AlQadîr: Al-Jâmi' baina Fannai AlRiwâyah wa Al-Dirâyah min 'Ilm AlTafsîr”, ed. Yûsuf Al-Ghûsy. Beirut: Dâr Al-Ma'rifah.

Utsaimîn, Muhammad ibn Shâlih Al-. 1415 H. "Syarh Al-'Aqîdah Al-Wâsithiyyah li
Syaikh Al-Islâm Ibn Taimiyyah”, Damam: Dâr Ibn Al-Jauzî.

Utsaimîn, Muhammad ibn Shâliḥ Al-. 2004. "Syarh Kitâb Al-Siyâsah AlSyar'iyyah li Syaikh Al-Islâm Ibn Taimiyyah”, Oman: Al-Dâr Al'Utsmâniyyah dan Dâr Ibn Hazm Beirut. 
